\title{
Child Right- Based Approach Dalam Peningkatan Self-Esteem Anak Usia Sekolah Dasar
}

\author{
Ratna Said \\ Prodi Pendidikan Guru Sekolah Dasar, Universitas Muhammadiyah Buton \\ ratnasaidppsunj@gmail.com
}

\begin{abstract}
This study aims to determine the Child-Right Based Approach in increasing SelfEsteem of elementary school aged children. This research is a qualitative research which is literature study or library research. Child Right-Based Approach in increasing self-esteem of elementary school age children: a) non-discrimination; the shortcomings of the child do not make the child lose his / her rights; b) the right to survival and development; $c)$ the child's right to participate in decision making can increase children's self-esteem; 4) child-friendly laws.
\end{abstract}

\section{Key Words: Self-Esteem, Elementary School Age Children, Child Right-Based Approach}

Abstrak. Penelitian ini bertujuan untuk mengetahui child- right based approach dalam peningkatan self- esteem anak usia sekolah dasar. Penelitian ini merupakan penelitian kualitatif yang bersifat studi pustaka atau library research. Child right- based approach dalam peningkatan selfesteem anak usia sekolah dasar: a) nondiskriminasi; kekurangan yang dimiliki oleh anak ditidak membuat anak kehilangan haknya; b)hak atas kelangsungan hidup dan perkembangan; c) hak anak untuk berpartisipasi dalam pengambilan keputusan dapat meningkatkan self -esteem anak; 4) undangundang yang lebih ramah terhadap anak.

\section{Kata Kunci: Self-Esteem, Anak Usia Sekolah Dasar, Child Right-Based Approach}

\section{PENDAHULUAN}

Anak Usia Sekolah Dasar pada dasarnya memiliki kepribadian yang belum matang, karena mareka masih dalam tahap pembentukan kepribadian. Pada tahap pembentukan kepribadian ini, perhatian dan pendampingan dari orang tua sangat dibutuhkan agar anak mendapatkan kepribadian yang baik. Untuk membentuk kepribadian yang baik ini memang tidak mudah, perlu terus dilakukan pendampingan secara berkelanjutan dikarenakan kepribadian bersifat dinamis atau tidak mutlak atau dengan kata lain, kepribadian akan mudah berubah sesuai dengan faktor yang memengaruhinya. Perubahan-perubahan dan tidak terpenuhinya hak anak baik dalam keluarga maupun lingkungan sosial sering sekali menjadi masalah kepribadian anak jika anak dalam kondisi low self-esteem atau harga diri yang rendah. Saat anak dalam kondisi low selfesteem, anak memiliki masalah dengan kebernilaian dirinya dalam kelompok atau lingkungan sosial dimana ia berada maka tentu saja akan mengakibatkan gangguan mental seperti depresi, kecemasan, gangguan belajar. Anak dengan low self-esteem sering sering menjadi korban kekerasan atau bullying. (KPAI, 2020) menunjukkan data dalam kurun waktu 9 tahun, dari 2011 sampai 2019, ada 37.381 pengaduan kekerasan terhadap anak. Untuk Bullying baik di pendidikan maupun sosial media, angkanya mencapai 2.473 laporan dan trennya terus meningkat. Berdasarkan uraian tersebut maka penulis tertarik untuk melakukan penelitian childright based approach dalam peningkatan selfesteem anak usia sekolah dasar..

\section{METODE PENELITIAN}

Penelitian ini merupakan penelitian kualitatif yang bersifat studi pustaka atau library research. Sebagai penelitian kepustakaan, maka sumber data penelitian ini 
adalah data-data kepustakaan. Data dikumpulkan dengan cara mencari, memilih, menyajikan dan menganalisis data-data literatur atau sumber-sumber yang berkaitan dengan permasalahan. Penelitian dilakukan pada bulan Oktober 2018.

\section{HASIL DAN PEMBAHASAN Anak Usia Sekolah Dasar}

(Abdullah, Boedi, 2012) 'masa anak sekolah (early childhood), pada masa ini anak memasuki masa belajar di dalam dan di luar sekolah'. Terdapat banyak aspek perilaku yang dapat dibentuk melalui penguatan verbal, keteladanan, dan identifikasi. Sehingga pada masa ini anak harus menjalani tugas-tugas perkembangan: a) belajar keterampilan fisik untuk permainan biasa;b) membentuk sikap sehat mengenai dirinya sendiri; c) bergaul dan belajar dengan teman-temannya; d) belajar peranan jenis yang sesuai dengan jenisnya; e) membentuk keterampilan dasar, seperti membaca, menulis dan berhitung; f) membentuk konsep-konsep yang perlu untuk sehari-hari; g) membentuk hati nurani, nilai moral, dan nilai sosial; h) memperoleh kebebasan pribadi; i) membentuk sikap terhadap kelompok sosial dan lembaga. Dalam perkembangan ini anak tetap membutuhkan: a) penambahan pengetahuan melalui belajar; b) memperoleh perhatian dan perilaku pujian atas prestasi-prestasinya, baik di rumah maupun disekolah; c) memerlukan pengawasan dari guru dan orang tua untuk memunculkan kebiasaan yang baik dan keterampilan baru. Selanjutnya, (Danim \& Khairil, 2010) 'fase sekolah: Umur 6-12 tahun'. Tahap ini dikatakan tahap latency, dimana anak dapat menciptakan dan menyelesaikan berbagai keterampilan baru dan pengetahuan atau tahap mencipta. Tahap ini juga sangat penting bagi pengembangan sosial anak. Jika anak mengalami ketidakcukupan kemampuan dan inferioritas diantara temantemanya, maka anak dapat megalami masalah serius dalam hal kompetensi dan harga diri (self-esteem).

\section{Self-esteem}

(Srisayekti \& Setiady, 2015) 'harga-diri (self-esteem) adalah bagaimana seseorang memandang dirinya sendiri'. Dari pendapat tesebut diketahui bahwa memandang diri sendiri adalah mencari tahu bagaimana sebenarnya diri atau citra diri kita sendiri dari sudut padang sendiri. Dengan memandang diri sendiri maka kita akan mengetahui kelebihan dan kekurangan diri sendiri. Setelah mengetahui kelebihan maka kelebihan tersebut terus ditingkatkan begitu juga setelah mengetahui kekurangan diri sebagai kelemahan maka dilakukan perbaikan atau peningkatan. Sedangkan menurut (Silverthorn et al., 2017) 'self-esteem adalah keberhargaan atau kebergunaan diri dalam menjalani kehidupan'. Dari pendapat tersebut diketahui bahwa pengakuan atas kemampuan dalam mengerjakan suatu pekerjaan merupakan selfesteem. Pujian sebagai penghargaan atas keberhasilan anak dalam mengerjakan suatu pekerjaan akan dapat meningkatkan selfesteem anak karena hal tersebut merupakan dorongan positif bagi anak untuk terus meningkatkan potensi dirinya. Selanjutnya, (Refnadi, 2018) 'self-esteem adalah; (1) penilaian seseorang secara umum terhadap dirinya'. Hal ini berati penilaian orang lain sangat berpengaruh pada self- esteem. Jika anak mendapatkan penilaian positif dari orang lain misalnya orang tua, maka anak akan mendapatkan konsep positif tentang diri dan kemampuanya. Akan tetapi jika anak mendapatkan kritikan yang berlebihan maka anak akan mendapatkan konsep yang negatif terhadap diri dan kemampuanya. Atau membandingkan kemampuan anak dengan anak lain yang kemampuannya lebih dari dia maka akan membuat anak berfikir bahwa ia tidak mampu atau tidak memiliki kemampuan sehingga akan berujung pada low self-esteem. (2) 'kemampuan untuk memahami apa yang dapat dilakukan dan apa yang telah dilakukan', Disini saat anak sudah mengetahui seberapa jauh kemampuan yang ia miliki dan prestasi apa yang telah ia raih maka akan membuat anak lebih menghargai dirinya sendiri. (3) 
'penetapan tujuan dan arah hidup sendiri', Dimana anak dapat membuat keputusan yang berkaitan dengan dirinya sendiri. (4) 'kemampuan untuk percaya pada kemampuan sendiri, dan tidak merasa iri terhadap prestasi orang lain'. Rasa iri hati dalam batas tertentu adalah normal. Iri terhadap prestasi anak lain secara berkelanjutan dan berlebihan dapat menyebabkan depresi, dendam, amarah, frustasi, stress dan rendah diri. Disini orang tua dapat memberikan pengertian kepada anak bahwa setiap anak memiliki bakat, kelebihan, keunikan yang berbeda antara anak yang satu dengan yang lainnya sehingga anak dapat menghargai kemampuan atau potensi yang dimilikinya.

Berkaitan dengan self- esteem (D'Mello et al., 2018) menyatakan bahwa 'self-esteem is self-assessment; this perception and evaluation can be positive or negative and pleasant or unpleasant'. Yang berarti harga diri adalah penilaian diri, dimana seseorang mampu memperoleh gambaran atau informasi tentang diri sendiri yang meliputi sifat baik atau buruk, motivasi baik atau buruk, perasaan sedih atau senang, emosi yang stabil atau tidak stabil dan mampu melakukan evaluasi diri sendiri atau mengoreksi diri untuk menjadi pribadi yang lebih baik. Senada dengan pendapat sebelumnya (Emler, 2002) menyatakan bahwa 'self-esteem is a generalised feeling about the self, and the view that it is the sum of a set of judgements about one's value, worthiness, and competence in various domains'. Hal ini berarti bahwa harga diri adalah perasaan umum tentang diri, dan pandangan bahwa itu adalah jumlah dari serangkaian penilaian tentang nilai, kelayakan, dan kompetensi seseorang di berbagai domain.

Dari beberapa pendapat ahli diatas maka dapat disimpulkan self-esteem adalah value diri seseorang yang didapatkan dari sudut pandang diri sendiri dan orang lain atas pengakuan prestasi atau kemampuanyang dimiliki untuk menyelesaikan suatu kegiatan atau masalah.

\section{Child- Right Based Approach}

(Trap \& Dixon, 2019)' a child rights-based approach is a conceptual framework for the process of human development that is normatively based on international children's rights standards and operationally directed to promoting, protecting and fulfilling children's human rights'. Pada dasarnya, pendekatan berbasis hak anak mengintegrasikan norma, standar dan prinsip sistem hak asasi manusia internasional ke dalam rencana, kebijakan dan proses pengembangan program untuk anak. (Barnen, 2020) 'Save the Children's strategy defines our activity as a child rights based approach'.

Prinsip-prinsip utama Konvensi Hak Anak dalam Child-Right Based Approach: a) Nondiskriminasi: kelompok anak yang berisiko tinggi mengalami diskriminasi, misalnya karena kecacatan. Sangat penting untuk menggugah kesadaran masyarakat khususnya orang tua untuk tidak melakukan diskriminasi pada ada yang cacat atau difabel. Dalam lingkungan keluarga, masih banyak orang tua yang belum dapat menerima kenyataan memiliki anak yang kondisinya berbada dengan anak-anak yang normal. Banyak orang tua yang merasa malu dan menyembunyikan kondisi anak mereka. Akibatnya, kondisi anak menjadi semakin terpuruk karena tidak mendapat cukup perhatian, anak menjadi low self -esteem pada hal anak sebenarnya memiliki banyak potensi dalam diri mereka walaupun dalam keadaan cacat. Disini diberikan pendampingan atau parenting bagi orang tua yang memiliki anak difabel agar mampu menerima kondisi anak mereka dan mampu menangani anak agar dapat berkembang maksimal. Dalam lingkungan sosial anak difabel kerap menjadi korban bullying dari rekan-rekanya. Disini anak diberikan pendampingan dan mendorong anak difabel mengembangkan potensinya dan melawan bullying atas diri mereka. b) Hak atas kelangsungan hidup dan perkembangan: Anak mendapatkan perlindungan dengan segala kegiatan untuk menjamin dan melindungi anak dan hak-haknya agar dapat hidup, tumbuh, 
berkembang dan berpartisipasi secara optimal sesuai dengan harkat dan martabat kemanusiaan. Pada kenyataanya masih banyak anak yang tidak mendapatkan perlindungan misalnya domestic violence, dimana anak mendapatkan kekesaran atau pelecehan atau eksploitasi seksual dari keluarga atau orang terdekat bahkan dilingkungan sekolah. Hal ini tentu saja berdampak pada self-esteem anak. Anak akan merasa tidak punya harga diri setelah mendapat perlakuan buruk tersebut. Perlindungan ini harusnya menjamin bahwa anak tidak dirugikan. Anak mendapatkan apa yang dibutuhkan untuk dapat bertahan hidup, berkembang dan tumbuh. c) Partisipasi: anak dilibatkan dalam proses pengambilan keputusan tentang segala sesuatu yang berhubungan dengan dirinya, dimana anak diminta dengan baik serta atas kemauan sendiri sehingga anak dapat menikmati dan bertanggungjawab dengan keputusan yang dibuat. Mendukung anak-anak di mana saja untuk mengekspresikan pandangan mereka, dan mendengarkan aspirasi dan membiarkan mereka berpartisipasi dalam pengambilang keputusan dapat meningkatkan self-esteem anak. d) Kepentingan yang terbaik untuk anak tentu saja tidak dapat terwujud kecuali jika anak-anak didengarkan dengan peka.Tidak hanya itu, perlu dibuat undang-undang undang-undang lebih ramah anak, misalnya Saat anak mendapatkan pelecehan seksual disekolah, kejadian selalu ditutup-tutupi untuk menjaga nama baik sekolah. Karena sebagian besar undang-undang setidaknya secara tidak langsung mempengaruhi anak, diberikan dukungan legislator dalam membuat penilaian dampak anak sehingga kepentingan anak dapat dipertimbangkan baik dalam jangka pendek maupun jangka panjang.

\section{KESIMPULAN}

Dari uraian teori diatas maka dapat disimpulkan:

1. Self-esteem adalah value diri seseorang yang didapatkan dari sudut pandang diri sendiri dan orang lain atas pengakuan kemampuan yang dimiliki untuk menyelesaikan suatu kegiatan atau masalah.

2. Child Right- Based Approach dalam peningkatan self-esteem anak usia sekolah dasar: a) nondiskriminasi; kekurangan yang dimiliki oleh anak ditidak membuat anak kehilangan haknya; b)hak atas kelangsungan hidup dan perkembangan; c) hak anak untuk berpartisipasi dalam pengambilan keputusan dapat meningkatkan self -esteem anak; 4) undang-undang yang lebih ramah terhadap anak.

\section{SARAN}

Perlu dilakukan penelitian lanjutan mengenai child-right based approach dalam peningkatan self- esteem anak usia sekolah dasar dengan menggunakan metode penelitian yang lainnya.

\section{UCAPAN TERIMA KASIH}

Terimakasih kepada Universitas Muhammadiyah Buton, Fakultas Keguruan dan Ilmu Pendidikan Program Studi Pendidikan Guru Sekolah Dasar dan seluruh pihak yang terlibat dalam penelitian ini.

\section{DAFTAR PUSTAKA}

Abdoelah, Boedi. (2012). Psikologi Perkembangan dan Pendidikan. CV. Pustaka Setia: Jawa Barat.

Barnen, Rädda. (2020). 'Child rights based approach to programming'. [Online]. Available:https://www.pelastakaalap set.fi/en/childrens-rights-are-thebasis-for-our-work/child-rightsbased-approach-to-programming/

D’Mello, L., Monteiro, M., \& Pinto, N. (2018). A study on the self-esteem and academic performance among the students. International Journal of Health Sciences and Pharmacy (IJHSP), 2(1). https://doi.org/10.528 81/zenodo.1156448

Danim, Sudarwan \& Khairil. (2010). Psikologi Pendidikan (Dalam Perspektif Baru). ALFABETA: Bandung. 
Dixon, Peter \& Annabel Trapp. (2019). "Child Rights-Based Approaches (Advanced Course)". [Online]. Available: http://www.hrea.org/learn/elearning/ childrightsprogramming/\#: :text=A\%20c hild\%20rights\%2Dbased\%20approac h,and $\% 20$ fulfilling $\% 20$ children's $\% 2$ 0human\%20rights.

Emler, N. (2002). The costs and causes of low self-esteem. Youth Studies Australia.

KPAI. (2020). Sejumlah Kasus Bullying Sudah Warnai Catatan Masalah Anak di Awal 2020, Begini Kata Komisioner KPAI. [Online). Available: https://www.kpai.go.id/berita/sejuml ah-kasus-bullying-sudah-warnaicatatan-masalah-anak-di-awal-2020begini-kata-komisioner-kpai

Refnadi, R. (2018). Konsep self-esteem serta implikasinya pada siswa. Jurnal EDUCATIO: Jurnal Pendidikan Indonesia, $\quad 4(1), \quad 16$. https://doi.org/10.29210/120182133

Silverthorn, N., DuBois, D. L., Lewis, K. M., Reed, A., Bavarian, N., Day, J., Ji, P., Acock, A. C., Vuchinich, S., \& Flay, B. R. (2017). Effects of a schoolbased social-emotional and character development program on self-esteem levels and processes: A clusterrandomized controlled trial. SAGE Open, 7(3). https://doi.org/10.1177/21582440177 13238

Srisayekti, W., \& Setiady, D. A. (2015). Harga-diri (Self-esteem) Terancam dan Perilaku Menghindar. Jurnal Psikologi, $\quad 42(2), \quad 141$. https://doi.org/10.22146/jpsi.7169 